\title{
TOWARDS AN INTRAOPERATIVE ENGINEERING OF OSTEOGENIC AND VASCULOGENIC GRAFTS FROM THE STROMAL VASCULAR FRACTION OF HUMAN ADIPOSE TISSUE
}

\author{
A.M. Müller ${ }^{1}$, A. Mehrkens ${ }^{1}$, D. J. Schäfer ${ }^{1}$, C. Jaquiery ${ }^{1}$, S. Güven ${ }^{1}$, M. Lehmicke², R. Martinetti ${ }^{3}$, I. Farhadi ${ }^{4}$, M. $^{2}$ \\ Jakob $^{1}$, A. Scherberich ${ }^{1}$, and I. Martin ${ }^{1 *}$
}

${ }^{1}$ Departments of Surgery and of Biomedicine, University Hospital Basel, CH-4031 Basel, Switzerland

${ }^{2}$ Synthes Biomaterials, West Chester, PA 19380, USA

${ }^{3}$ Fin-Ceramica Faenza S.p.A., I-48018 Faenza (RA), Italy

${ }^{4}$ Farhadi Iradj Dr. med. FMH, CH-8603 Schwerzenbach, Switzerland

\begin{abstract}
Grafts generated by cultivation of progenitor cells from the stromal vascular fraction of human adipose tissue have been proven to have osteogenic and vasculogenic properties in vivo. However, in vitro manufacture of such implants is challenged by complex, impractical and expensive processes, and requires implantation in a separate surgery. This study investigates the feasibility of an intraoperative approach to engineer cell-based bone grafts with tissue harvest, cell isolation, cell seeding onto a scaffold and subsequent implantation within a few hours. Freshly isolated adipose tissue cells from a total of 11 donors, containing variable fractions of mesenchymal and endothelial progenitors, were embedded at different densities in a fibrin hydrogel, which was wrapped around bone substitute materials based on beta-tricalcium phosphate $\left(\right.$ ChronOS $\left.^{\circledR}\right)$, hydroxyapatite $\left(\right.$ Engipore $\left.^{\circledR}\right)$, or acellular xenograft $\left(\mathrm{Bio}^{-O s s^{\circledR}}{ }^{2}\right.$. The resulting constructs, generated within 3 hours from biopsy harvest, were immediately implanted ectopically in nude mice and analysed after eight weeks. All explants contained blood vessels formed by human endothelial cells, functionally connected to the recipient's vasculature. Human origin cells were also found within osteoid structures, positively immunostained for bone sialoprotein and osteocalcin. However, even with the highest loaded cell densities, no frank bone tissue was detected, independently of the material used. These results provide a proof-of-principle that an intraoperative engineering of autologous cell-based vasculogenic bone substitutes is feasible, but highlight that - in the absence of in vitro commitment - additional cues (e.g., low dose of osteogenic factors or orthotopic environmental conditions) are likely needed to support complete osteoblastic cell differentiation and bone tissue generation.
\end{abstract}

Keywords : Intraoperative, osteogenic, vasculogenic, tissue engineered grafts, human, adipose-derived cells, ceramic materials.

\section{* Address for correspondence}

Ivan Martin

Institute for Surgical Research and Hospital Management University Hospital Basel

Hebelstrasse 20, CH-4031 Basel, Switzerland

Telephone Number: $+41(0) 612652384$

FAX Number: $+41(0) 612653990$

E-mail: imartin@uhbs.ch
Introduction

The engineering of osteogenic bone substitute grafts based on scaffolds loaded with osteoprogenitors offers an attractive opportunity for the replacement of posttraumatic bone loss, treatment of delayed or non healing fractures or fusion of degenerated joints (Cancedda et al., 2003). The concept has the potential to overcome the main limits associated with autologous bone, currently the golden standard bone graft, namely donor site morbidity (Ahlmann et al., 2002; Arrington et al., 1996; Niedhart et al., 2003; Sasso et al., 2005; Silber et al., 2003) and reduced availability (Boden, 2000; Younger and Chapman, 1989). However, in addition to the reported challenges in reproducibility of performance (Meijer et al., 2007), routine clinical implementation of autologous cell-based engineered bone grafts is challenged by the complexity, impracticality and high costs of the manufacturing process (Evans et al., 2007). This is predominantly due to the need for two surgical procedures (respectively for cell harvest and graft implantation) and extensive ex vivo cell manipulation and culture under Good Manufacturing Production regulations/facilities.

Engineering of autologous osteogenic grafts would have the potential to become more simple, practical and economical if the manufacturing process was reduced to the timeline of a single surgical procedure. An intraoperative approach was proposed starting from bone marrow-derived mesenchymal stromal cells, either immunoselected for CD105 (Aslan et al., 2006) or in combination with a gene therapy approach (Evans et al., 2007). Considering that clonogenic osteoprogenitor cells (colony forming unit-fibroblasts, CFU-f) are present in human fresh bone marrow biopsies at low frequencies (about $0.01 \%$ of the total mononucleated cells), further decreasing with donor age (Muschler et al., 2001), their availability could become a limiting factor, especially for the reconstruction of large bone defects. In this context, it was proposed that the stromal vascular fraction (SVF) of adipose tissue could represent a more suitable cell source for a one-step surgical procedure (Helder et al., 2007). Indeed, clonogenic mesenchymal cells in SVF from human lipoaspirates are about $5 \%$ of the total cell population, corresponding - when normalized to the biopsy volume - to around 500-fold larger numbers than in human bone marrow aspirates (Fraser et al., 2006; Scherberich et al., 2007). Moreover, SVF cells are known to include a fraction of endothelial lineage cells (PlanatBenard et al., 2004), which could play an important role 
in the crucial process of graft vascularization (Scherberich et al., 2007). However, despite promising perspectives, to the best of our knowledge it has not yet been convincingly demonstrated that freshly harvested SVF cells can effectively induce bone tissue or enhance its repair. In fact, SVF cells did not generate frank bone tissue when implanted in a goat orthotopic intervertebral model (Helder et al., 2007), and were not capable to induce bone formation when grafted subcutaneously in a rabbit model (Follmar et al., 2007).

We recently demonstrated that human SVF cells, seeded and cultured for 5 days within 3D porous ceramic scaffolds using a perfusion-based bioreactor system, generated grafts capable to induce ectopic bone formation in nude mice, as well as a network of blood vessels functionally connected to the host vasculature (Scherberich et al., 2007; Müller et al., 2009). Supported by those promising findings, in the present study we aimed at developing osteogenic and vasculogenic grafts using human SVF cells in a setting compatible with an intraoperative clinical implementation. In particular, freshly harvested SVF cells were associated to different types of scaffolds including a mineral/ceramic component, and implanted ectopically in nude mice without pre-culture. Based on the need to rapidly generate the constructs, a fibrin gel was used to embed the cells and to wrap them around the scaffolds.

\section{Materials and Methods}

\section{Cell isolation}

Subcutaneous adipose tissue was obtained in the form of lipoaspirates $(n=3)$ or excised fat samples $(n=8)$ from 11 healthy donors ( 10 female, 1 male; mean age $32 \pm 15$ years) undergoing abdominal wall plasty $(\mathrm{n}=5)$, breast reduction $(n=3)$ or routine liposuction of the thigh and the abdominal wall ( $n=2$ and $n=1$ respectively). All donors gave their informed consent and the study protocol was approved by the local ethical committee. Excised fat samples were minced into pieces of 2-4 $\mathrm{mm}$ in diameter. Both minced fat and lipoaspirates were digested with $0.15 \%(\mathrm{~W} / \mathrm{V})$ type II collagenase for one hour at $37^{\circ} \mathrm{C}$ under orbital shaking. The suspension was then centrifuged at $400 \mathrm{~g}$ for 4 minutes. The resulting pellet was washed in phosphate buffered solution (PBS, Gibco, Invitrogen, Carlsbad, CA, USA), resuspended in $\alpha$-Modified Eagle's Medium ( $\alpha$-MEM, Gibco) containing $10 \%$ of foetal bovine serum (FBS, Gibco) and passed through a $100 \mu \mathrm{m}$ strainer. Red blood cells were lyzed by incubation for 5 minutes with a buffer containing $0.15 \mathrm{~mol} / 1$ ammonium chloride, $1.0 \mathrm{mmol} / \mathrm{l}$ potassium bicarbonate and $0.1 \mathrm{mmol} / \mathrm{l} \mathrm{Na}$-EDTA. After centrifugation and washing in PBS, the SVF cells were suspended in $\alpha$-MEM supplemented with $10 \%$ FBS and counted by using a Neubauer chamber.

\section{Cell characterisation}

The frequency of clonogenic cells among isolated SVF cells, also referred to as fibroblastic colony forming units (CFU-f), was determined by plating 500 freshly isolated SVF cells per $56 \mathrm{~cm}^{2}$ Petri dish in duplicates. The cells were then cultured for 14 days in $10 \%$ FBS containing $\alpha$ MEM supplemented with $5 \mathrm{ng} / \mathrm{ml} \mathrm{FGF-2} \mathrm{(thereafter}$ referred to as complete medium). The resulting colonies were stained with crystal violet and counted.

The phenotype of freshly isolated SVF cells was determined by cytofluorimetric analysis. Cells were incubated for 30 minutes with antibodies against the mesenchymal markers CD105 (conjugated with FITC, Serotec, Oxford, U.K.) and CD90 (FITC-conjugated, BD Bioscience, Franklin Lakes, NJ, USA), and against the endothelial markers CD31 and CD34 (PE- and APCconjugated respectively, both from BD Bioscience). Cells were washed, resuspended in PBS and analyzed by using a FACSCalibur flow cytometer (BD Bioscience).

\section{Fabrication and implantation of SVF cells-fibrin- scaffold constructs}

To obtain a fibrin mesh supporting cell proliferation and migration, fibrinogen and thrombin components from Tisseel VH S/D (Baxter BioScience, Vienna, Austria) were diluted and mixed as described by Bensaid et al. (Bensaid et al., 2003). The fibrinogen component (containing 75$115 \mathrm{mg} / \mathrm{ml}$ fibrinogen, $+3000 \mathrm{KIE} / \mathrm{ml}$ aprotinin) and the thrombin component (containing 400 -600 IU/1 thrombin $+40 \mathrm{mmol} / 1$ calcium chloride) were diluted respectively 3- and 4-fold using specific buffers provided by Baxter. These buffers were formulated to only dilute the protein components, while leaving the excipient and ionic environment of the components constant. Then, various amounts of freshly isolated SVF cells were loaded onto porous tri-calcium phosphate $\left(\right.$ Chronos $^{\circledR}$, Synthes, West Chester, PA, USA) or hydroxyapatite (Engipore ${ }^{\circledR}$, FinCeramica Faenza, Italy) cylinders (4mm height, $8 \mathrm{~mm}$ diameter) or blocks of acellular xenografts (Bio-Oss ${ }^{\circledR}$ collagen, Geistlich Pharma AG, Wolhusen, Switzerland, $4 \mathrm{~mm} \times 5 \mathrm{~mm} \times 6 \mathrm{~mm}$ beams) using fibrin gel as a cell carrier, as shown in Fig. 1. Briefly, freshly isolated adipose tissue derived cells were suspended in $150 \mu$ l of diluted fibrinogen component and mixed with an equal volume of the diluted thrombin component in a well. The resulting fibrin-cell matrix (Fig. 1A) was then wrapped around the above-mentioned scaffolds (Fig. 1B). Loaded scaffolds and the fabrication well were stained by Methyltetrazolium (MTT) to qualitatively assess efficiency and uniformity of cell loading after the wrapping process (Fig. 1 C,D). Upon fabrication, all constructs were maintained in a humidified incubator $\left(37^{\circ} \mathrm{C} / 5 \% \mathrm{CO}_{2}\right)$ for 15 minutes, cut in two halves and implanted in the subcutaneous tissue of different nude athymic mice (CD1 nu/nu, Charles River, Sulzfeld, Germany). The total construct preparation time, starting from the harvest of the tissue biopsy to the implantation, was typically within 3 hours. Eight weeks after implantation, the mice were sacrificed by inhalation of $\mathrm{CO}_{2}$. The constructs were harvested, fixed in a $4 \%$ formalin buffer overnight and processed as described below.

\section{Assessment of in vivo bone formation}

Decalcification of the constructs was performed by incubation with Osteodec ${ }^{\circledR}$ (Bio Optica, Milan, Italy) at $37^{\circ}$ for 3-4 hours on an orbital shaker. Decalcified 


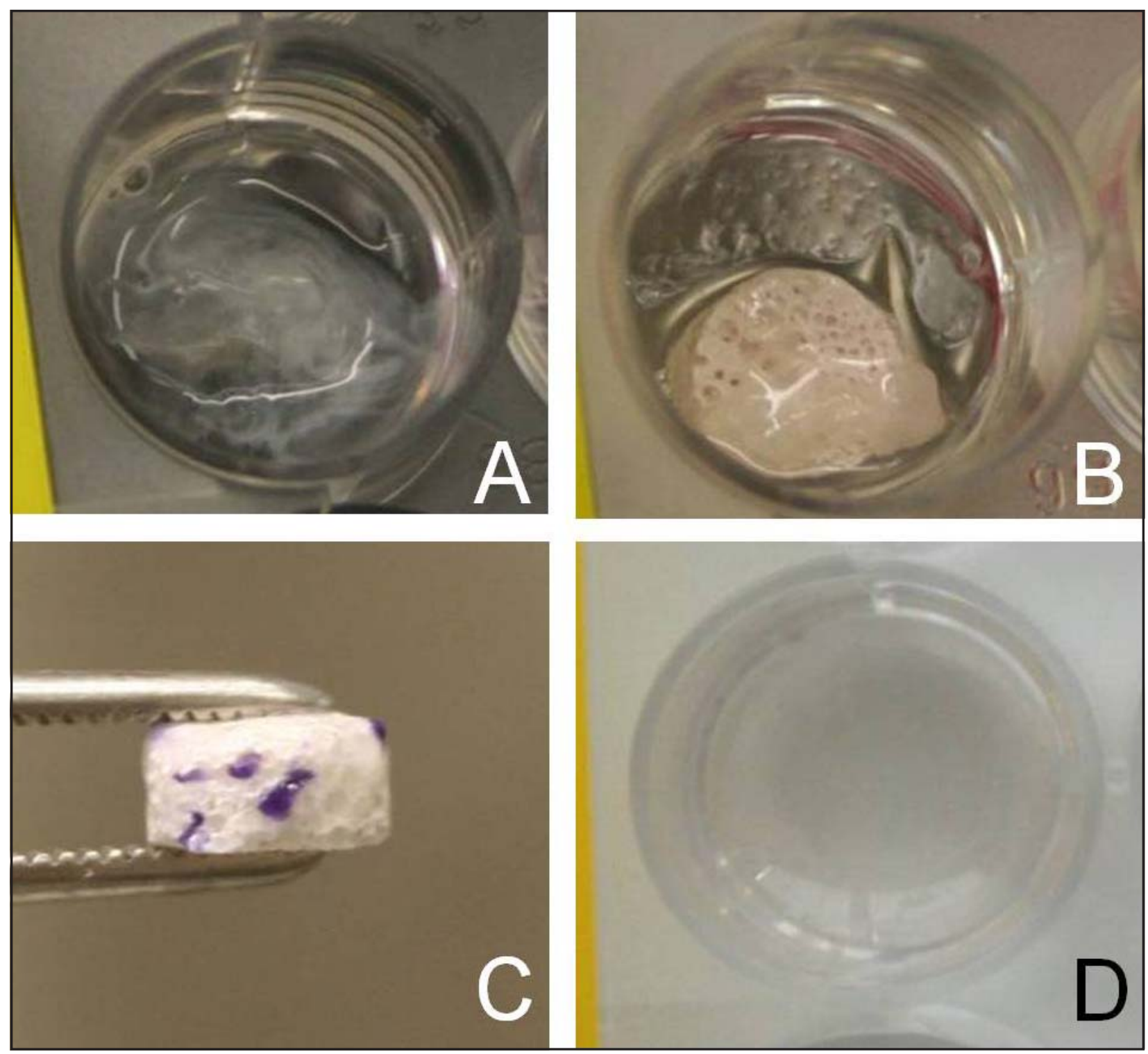

Fig. 1: Loading of SVF cells on scaffolds by embedding cells in a fibrin matrix and subsequent wrapping around the scaffolds (process illustrated for the loading of an Engipore ${ }^{\circledR}$ scaffold). Freshly isolated adipose tissue derived cells were suspended in $150 \mu \mathrm{l}$ of the fibrinogen component and transferred into a well. The cell suspension was then mixed with an equal volume of thrombin. The resulting fibrin-cell matrix (A) was then wrapped around the scaffolds (B). MTT staining showed a rather scattered distribution of SVF cells on the surface of the scaffold (C) but no cells remaining in wells (D) following the loading process.

Abbreviations: SVF: stromal vascular fraction, MTT: Methyl tetrazolium

constructs were paraffin-embedded and sectioned $(7 \mu \mathrm{m}$ thick). Sections were stained with Haematoxylin \& Eosin and Masson's trichrome and observed by light and fluorescence microscopy.

For further analysis of bone formation, immunostaining with polyclonal rabbit antibodies against human bone sialoprotein (Immunodiagnostik AG, Bensheim, Germany) and human osteocalcin (Chemicon/Millipore, Billerica, MA, USA) was performed and visualised by ABC alkaline phosphatase complex kit (Dako, Glostrup, Denmark), followed by counterstaining with haematoxylin.

To distinguish between human and recipient (mouse) cells, we performed in situ hybridization for ALU sequences, specific of the human genome, and immunostaining for HLA-ABC. For in situ hybridization, sections were incubated with pepsin at $37^{\circ} \mathrm{C}$ for 5 minutes followed by irrigation with $100 \%$ ethanol for 10 seconds and distilled water for 30 seconds. Hybridization with a biotin conjugated DNA probe (ZytoVision, Bremerhaven, Germany) specific for ALU sequences was carried out according to manufacturer's instructions. The biotin conjugated DNA probe was detected by addition of alkaline phosphatase complex (Dako) and subsequent staining with fast red. Immunohistofluorescence staining for HLA-ABC was carried out on sections with a monoclonal HLA-ABC-biotin conjugated antibody (Cedarlane Labs, Burlington, Ont., Canada) and subsequent incubation with avidin-FITC (BD Bioscience).

\section{Assessment of in vivo blood vessel formation}

To demonstrate the presence of donor-derived functional blood vessels, we performed immunohistochemistry using 


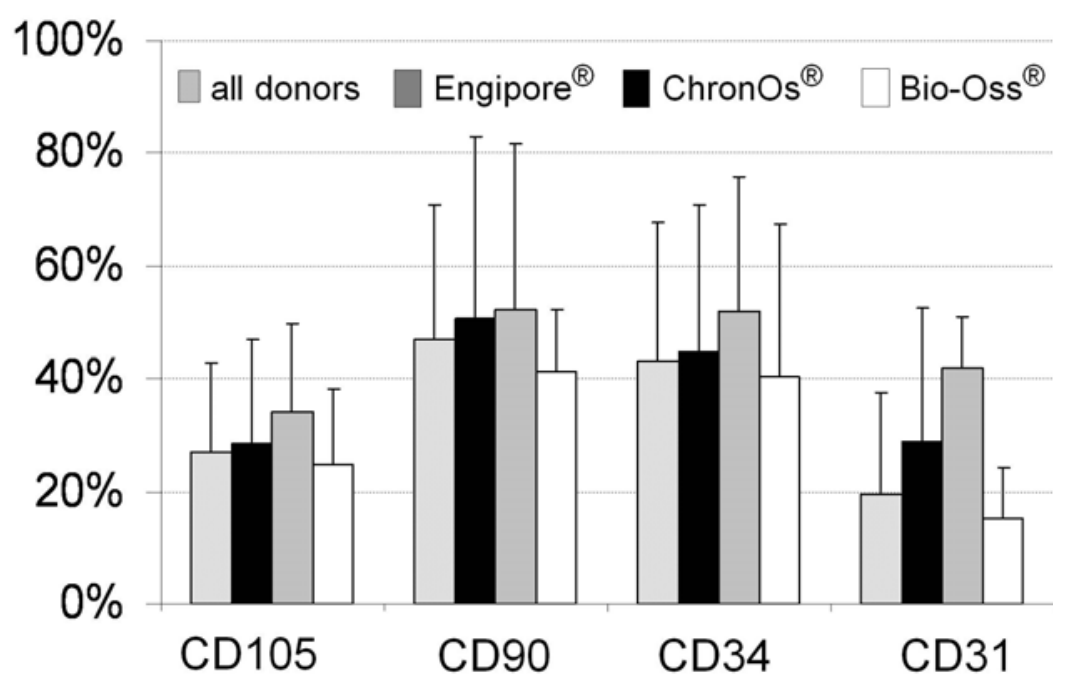

Fig. 2: Expression of mesenchymal (CD105 and CD90) as well as endothelial (CD34 and CD31) markers in the stromal vascular fraction (SVF) of all donors (first column) and in the SVF of donors allocated to the different scaffold types.

a biotin-conjugated antibody directed specifically against the human isoform of CD34 (Chemicon/Millipore). Prior to incubation with the antibody, de-paraffinized sections were immersed for 30 minutes in a target retrieval solution (Dako) at a temperature of $95^{\circ} \mathrm{C}$. The binding of the antihuman $\mathrm{CD} 34$ was visualised by $\mathrm{ABC}$ alkaline phosphatase complex kit (Dako).

\section{Results and Discussion}

\section{Cell isolation and characterization}

After the digestion of adipose tissue and subsequent centrifugation, the resulting SVF yielded $1.7 \times 10^{5} \pm 1.2 \times 10^{5}$ nucleated cells, of which $7.0 \% \pm 5.7 \%$ were clonogenic, colony-forming cells (typically referred to as CFU-f). The high variation of nucleated cells frequency per volume of harvested adipose tissue was due to substantially lower yields obtained from one excised breast fat sample and from one lipoaspirate $\left(4.5 \times 10^{3}\right.$ and $4.7 \times 10^{4}$ nucleated cells/ $\mathrm{ml}$ of harvested tissue, respectively). Both samples were highly fibrous, possibly explaining the reduced efficiency in the cell isolation process. Since the clonogenic cell frequency in these two samples was in a typical range, the constructs generated from these donors were included for further analysis. Overall, the frequency of CFU-f did not substantially differ between samples used to load Engipore $^{\circledR}$ and ChronOS $^{\circledR}$ cylinders $(7.3 \pm 5.3 \%$ and $8.4 \pm 7.2 \%$, respectively), but happened to be lower in samples used to load Bio-Oss ${ }^{\circledR}$ blocks $(3.3 \pm 1.2 \%)$.

Engipore ${ }^{\circledR}$ and ChronOS $^{\circledR}$ cylinders were seeded with $8.3 \times 10^{6}-39.2 \times 10^{6}$ freshly isolated SVF cells $/ \mathrm{cm}^{3}$, corresponding to $1.2 \times 10^{5}-3.6 \times 10^{6} \mathrm{CFU}-\mathrm{f} / \mathrm{cm}^{3}$ in a total of 8 and 12 experiments, respectively. Bio-Oss ${ }^{\circledR}$ blocks were loaded with $8.3 \times 10^{6}-25.0 \times 10^{6}$ nucleated cells $/ \mathrm{cm}^{3}$, corresponding to $1.7 \times 10^{5}-1.1 \times 10^{6} \mathrm{CFU}-\mathrm{f} / \mathrm{cm}^{3}$, in a total of 7 experiments. MTT staining of cell-scaffold constructs and of the fabrication well following construct generation indicated a complete but rather scattered cell seeding on the scaffold surface (Fig. 1C,D), which could account for higher cell densities in localized areas. Efforts should be made in the future to reach a higher homogeneity of the cell seeding, for instance by mixing the polymerizing cellcontaining fibrin gel with the granulate ceramic scaffolds.

Cytofluorimetric analysis of SVF cells documented the presence of mesenchymal and endothelial lineage cells (Fig. 2). Their frequency was variable among different donors, as previously reported (Scherberich et al., 2007), but comparable between the samples allocated to the different scaffold groups.

\section{Assessment of in vivo bone formation by SVF cells}

After 8 weeks in vivo, in 11 out of 27 constructs implanted, corresponding to all samples seeded with more than $2.10^{6}$ CFU-f/ $\mathrm{cm}^{3}$ (Engipore or ChronOs), a very dense collagenous matrix was observed by standard H\&E and Masson Trichrome staining (Fig. 3C-F). This matrix resembled osteoid tissue, which is the organic, collagenrich portion of the bone matrix that forms prior to the maturation of bone tissue and its mineralization, and which is stained in green by Masson Trichrome. However, no frank bone, with its typical histological morphology, was observed. In contrast, when less than $2.10^{6} \mathrm{CFU}-\mathrm{f} / \mathrm{cm}^{3}$ were seeded, no such dense matrix was observed but a more fibrotic tissue was formed (Fig. 3A,B and G). It was retrospectively observed that since the Bio-Oss were seeded with cells from patients with low CFU-f frequencies, this resulted in the fact that only the experimental condition with less than 2 million CFU-f/ $\mathrm{cm} 3$ was assessed with this material. This is likely to explain why no dense matrix was formed in Bio-Oss (Fig. $3 \mathrm{G})$. When cell-free materials were implanted in vivo (Chronos ${ }^{\circledR}$ shown in Fig. 3H, other materials not shown), pores were filled only with adipose tissue and large calibre blood vessels arising from ingrowth of mouse tissue. The osteoid-like matrix observed with more than $2.10^{6} \mathrm{CFU}-\mathrm{f} /$ $\mathrm{cm}^{3}$ was strongly positive for typical osteoblastic markers such as bone sialoprotein and osteocalcin (Fig. 4A,B,C). Immunostaining for HLA-ABC (Fig. 4D,E) and in situ hybridization for ALU sequences (Fig. $4 \mathrm{H}$ ) demonstrated 
Engipore $^{\circledR}$

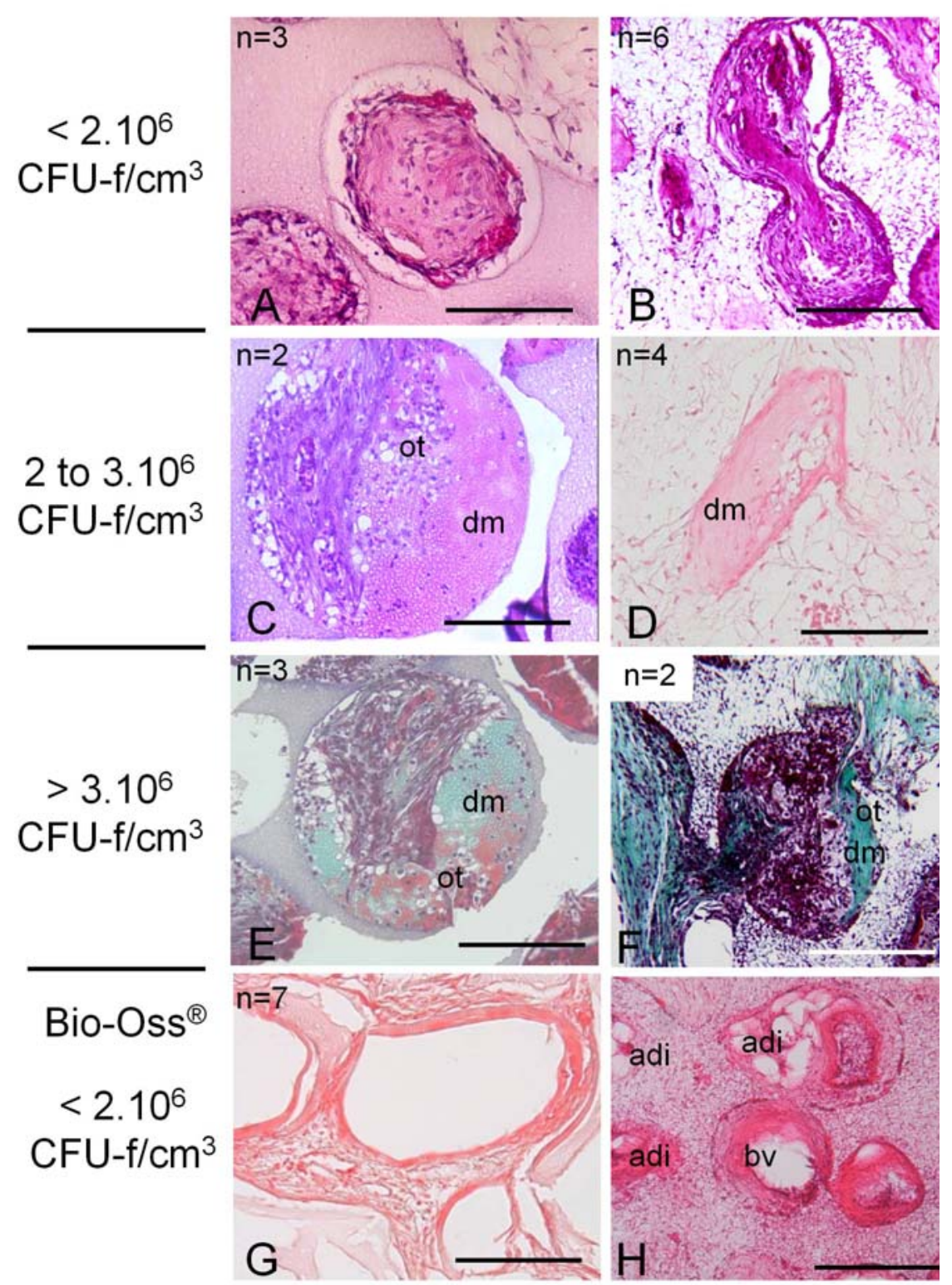

Fig. 3: Light microscopy pictures of hematoxylin and eosin $(\mathbf{A}, \mathbf{B}, \mathbf{C}, \mathbf{D}, \mathbf{G})$ and Masson trichrome (E,F)-stained sections of constructs ectopically implanted for 8 weeks in nude mice and generated by wrapping fibrin embedded SVF cells around ChronOS $^{\circledR}(\mathbf{B}, \mathbf{D}, \mathbf{F})$ or Engipore ${ }^{\circledR}$ $(\mathbf{A}, \mathbf{C}, \mathbf{E})$ cylinders, and blocks of Bio-Oss $^{\circledR}(G)$. A very dense matrix $(\mathrm{dm})$ was observed in all scaffold types when the initial density of clonogenic cells inside the scaffold was higher than $2.10^{6}$ clonogenic cells $/ \mathrm{cm}^{3},(\mathbf{C}-\mathbf{F})$, whereas mostly fibrotic tissue was formed with densities below $2.10^{6}$ clonogenic cells $/ \mathrm{cm}^{3}(\mathbf{A}, \mathbf{B})$. This dense matrix showed closer similarity to osteoid tissue (ot) in scaffolds initially loaded with more than $3.10^{6}$ clonogenic cells $/ \mathrm{cm}^{3}(\mathbf{E}, \mathbf{F})$, as shown by microscopy images of representative fields. (H) Represents the hematoxylin and eosin-stained section of a cell free ChronOs $^{\circledR}$ scaffold ectopically implanted for 8 weeks in nude mice showing ingrowths of mouse tissue, especially adipose tissue (adi) and blood vessels (bv). Scale bars $=100 \mu \mathrm{m}(\mathbf{A}, \mathbf{B}, \mathbf{C}, \mathbf{E}, \mathbf{F}, \mathbf{H})$ or $50 \mu \mathrm{m}$ (D). The number of independent donors tested for each condition is reported in the upper left corner of each image. the human origin of cells within this dense matrix. Interestingly, SVF cells, initially present only at the periphery of the scaffolds, invaded even the most central regions of the constructs in vivo. This process could have been facilitated by the specific fibrinogen and thrombin concentrations used, previously reported to support cell migration (Bensaid et al., 2003).

The absence of bone tissue formation observed in this study, at least in the time frame of 8 weeks, needs to be discussed in the context of the in vivo model used. In fact, we decided to test the intrinsic osteogenic properties of the grafts, and therefore implanted them in an ectopic environment, which does not include the biological and biomechanical cues present in proximity to bone tissue. Subcutaneous implantation is a stringent test of osteogenicity also for bone marrow-derived mesenchymal stromal cells, and was demonstrated to require (i) a mineralized surface for priming osteoblastic differentiation (Ohgushi et al., 1989; Ohgushi and Okumura, 1990; Eyckmans et al., 2009), and (ii) a critical density of implanted clonogenic cells (Braccini et al., 2005; Holy et al., 2000). In our study, these conditions were satisfied, since we loaded cells onto different types of calcium phosphate-based scaffolds, using a density of clonogenic cells largely exceeding the range $\left(2.5 \times 10^{5}-3 \times 10^{5}\right.$ clonogenic cells $/ \mathrm{cm}^{3}$ ) previously reported to support ectopic osteogenesis by human bone marrow-derived CFU-f (Braccini et al., 2005). Thus, the absence of frank bone formation suggests an intrinsically reduced osteogenic commitment of adipose tissue- vs. bone marrow-derived CFU-f. On the other hand, following short term cultivation ( 5 days) in a perfusion-based bioreactor, SVF cells from human adipose tissue were demonstrated to generate ectopic bone tissue (Scherberich et al., 2007). Although it is not clear which culture parameters were crucial in the process (e.g., flow induced shear, osteogenic medium supplements, 3D cell organization), the result confirms that the cells indeed have an osteogenic capacity, if appropriately triggered. In order to exploit such capacity within an intraoperative setting, future studies should investigate the effect of a short exposure of SVF cells to osteogenic growth factors (Helder et al., 2007; Aslan et 

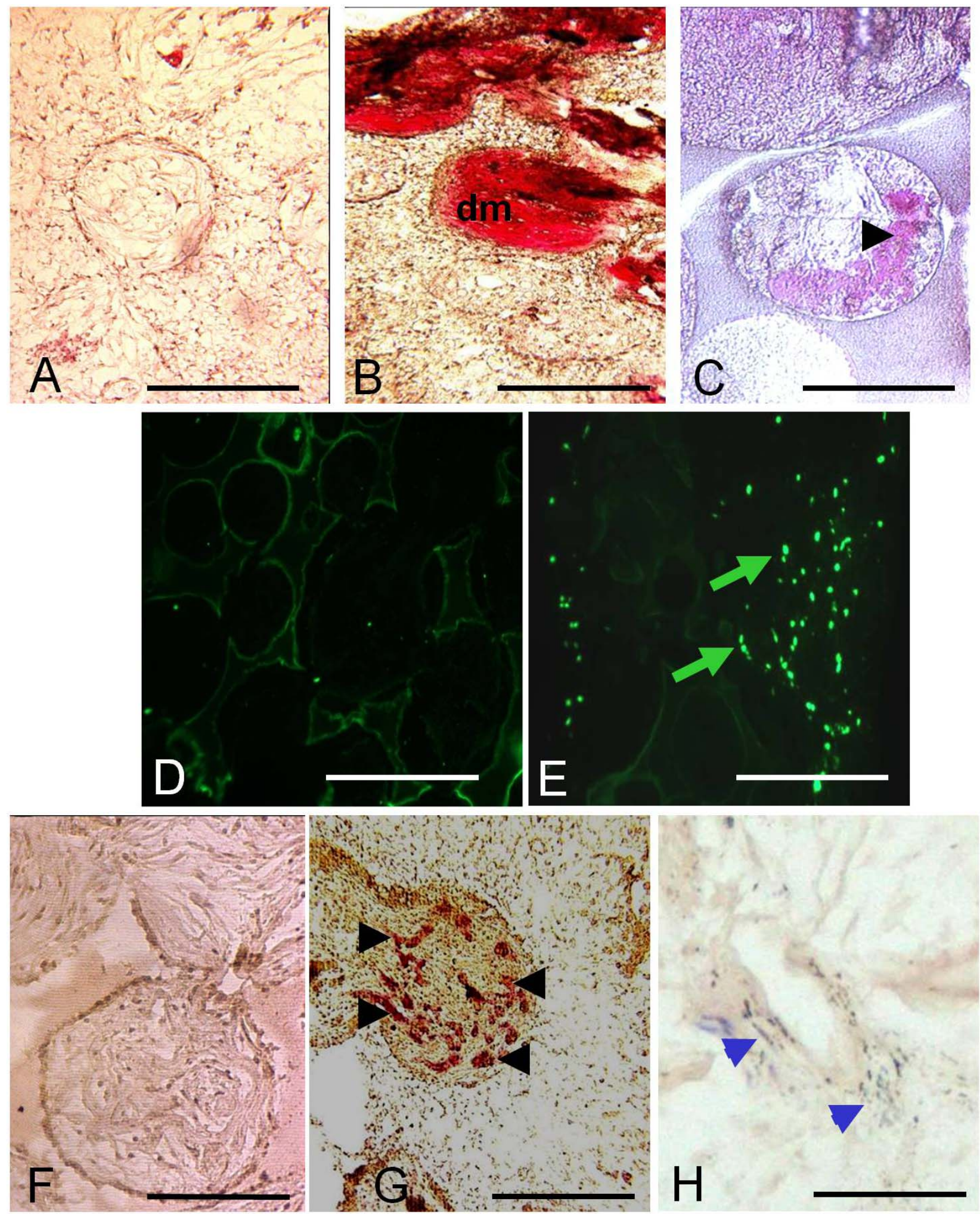

Fig. 4: Immohistochemistry (A,B,C,F,G), immunoflurorescence (D,E) and in situ hybridization (H) of explanted constructs. The dense matrix $(\mathrm{dm})$ was positively stained for bone sialoprotein (B, red staining) and osteocalcin $(\mathbf{C}$, pink staining shown by arrowhead). Isotype control antibodies showed no relevant unspecific binding (A). Explanted constructs included human donor-derived cells, as demonstrated by immunofluorescent staining for HLA-ABC (E, light green cells shown by green arrows) and in situ hybridization with probes for human-specific ALU sequences (H, blue nuclei shown by blue arrowheads). Isotype control for HLA-ABC showed no background staining (D). As demonstrated by staining for the human isoform of CD34 (G, isotype control shown in $\mathbf{F})$, a fraction of SVF cells supported the formation of functional blood vessels in vivo (red structures shown by arrowheads). Scaffolds used in the results shown were Engipore ${ }^{\circledR}(\mathbf{C}-\mathbf{E}, \mathbf{H})$ or $\operatorname{ChronOs}^{\circledR}(\mathbf{A}, \mathbf{B}, \mathbf{F}, \mathbf{G})$. Bars: $200 \mu \mathrm{m}$. 
al., 2006), supplemented into the culture medium or bound to the carrier material (Park et al., 2006), possibly at lower doses than those typically employed for cell-free osteoinductive grafts. Alternatively, scaffolds with more instructive chemical and structural characteristics (Ripamonti et al., 2008) should be coupled with freshly harvested SVF cells to prime their osteoblastic differentiation. Ultimately, however, tests of osteogenicity will have to be performed in an orthotopic, loaded in vivo model, still allowing the use of human-derived cells but more closely corresponding to a possible clinical scenario (e.g., using nude rats and the RatFix ${ }^{\mathrm{TM}}$ system, AO Foundation, Davos, Switzerland).

\section{Assessment of human blood vessel formation by SVF cells}

As shown in Fig. 4F,G, some blood vessels inside the constructs were lined with human (and not mouse) endothelial cells, as demonstrated by immunostaining for the human isoform of CD34. These blood vessels contained erythrocytes, indicating that they were functionally connected to the vasculature of the host. The human cellderived vascularization of the implant, so far not observed in previous constructs generated intraoperatively (Helder et al., 2007), appeared to be independent of the scaffold type used and of the number of cells initially loaded onto the scaffold. The reproducibility of donor-derived vascularization in the constructs suggests a strong vascular commitment of adipose tissue-derived endothelial precursors and underlines the previously reported capacity of SVF cells to support vascularization (Scherberich et al., 2007, Thangarajah et al., 2009). It remains to be demonstrated whether the presence of functional endothelial lineage cells will effectively accelerate or improve vascularization of the graft, which may become crucial in the process of scaling-up to critically sized dimensions.

\section{Conclusion}

In conclusion, this study describes the feasibility of a clinically-compliant method for the intraoperative generation of autologous bone substitute constructs, based on lipoaspirate cells. The preparation of the grafts was achieved within 3 hours from the biopsy harvest, and the times could be further reduced by appropriate selection of the enzyme combination and concentration, as well as by the availability of clinical grade devices for cell isolation from the adipose tissue (e.g., Celution ${ }^{\circledR}$ by Cytori Therapeutics, U.S.A or Sepax ${ }^{\circledR}$ by Biosafe, Switzerland). Overall, no major qualitative differences between the scaffolds were observed for parameters such as formation of dense tissue or of blood vessels by implanted cells. These cells had a reproducible vasculogenic capacity, whereas effective de novo bone formation in an ectopic mouse model could not be demonstrated. The result indicates that cell density or specific properties of the mineralized substrates used are not sufficient per se to instruct SVF cells to develop along the osteogenic lineage in an inert, ectopic environment. Future studies will thus have to test if short time stimulation of adipose tissue-derived cells with osteoinductive factors, or the use of an orthotopic model in a loaded skeletal area will possibly turn the premature osteoid matrix observed in the present study into mature bone, and thus open the way to a clinical testing of this approach.

\section{Acknowledgments}

We are grateful to Dr. Andreas Goessl (Baxter Biosurgery, Austria) and to Dr. Katja Martin (Geistlich Pharma AG, Switzerland) for the generous supply of respectively the Tissee ${ }^{\circledR}$ fibrin glue and the Bio-Oss ${ }^{\circledR}$ collagen material. We acknowledge the Swiss National Science Foundation for financial support (SNF grant \# 310030-120432).

\section{References}

Ahlmann E, Patzakis M, Roidis N, Shepherd L, Holtom P (2002) Comparison of anterior and posterior iliac crest bone grafts in terms of harvest-site morbidity and functional outcomes. J Bone Joint Surg Am 84: 716-720.

Arrington ED, Smith WJ, Chambers HG, Bucknell AL, Davino NA (1996) Complications of iliac crest bone graft harvesting. Clin Orthop Relat Res 329: 300-309.

Aslan H, Zilberman Y, Kandel L, Liebergall M, Oskouian RJ, Gazit D, Gazit Z (2006) Osteogenic differentiation of noncultured immunoisolated bone marrow-derived CD105+ cells. Stem Cells 24:1728-1737.

Bensaïd W, Triffitt JT, Blanchat C, Oudina K, Sedel L, Petite H (2003) A biodegradable fibrin scaffold for mesenchymal stem cell transplantation. Biomaterials 24: 2497-2502.

Boden SD (2000) Biology of lumbar spine fusion and use of bone graft substitutes: present, future, and next generation. Tissue Eng 6: 383-399.

Braccini A, Wendt D, Jaquiery C, Jakob M, Heberer M, Kenins L, Wodnar-Filipowicz A, Quarto R, Martin I (2005) Three-dimensional perfusion culture of human bone marrow cells and generation of osteoinductive grafts. Stem Cells 23:1066-1072.

Cancedda R, Dozin B, Giannoni P, Quarto R (2003) Tissue engineering and cell therapy of cartilage and bone. Matrix Biol 22: 81-91.

Evans CH, Palmer GD, Pascher A, Porter R, Kwong FN, Gouze E, Gouze JN, Liu F, Steinert A, Betz O, Betz V, Vrahas M, Ghivizzani SC. Facilitated endogenous repair: making tissue engineering simple, practical, and economical. Tissue Eng 13:1987-1993.

Eyckmans J, Roberts SJ, Schrooten J, Luyten FP (2009) A clinically relevant model of osteoinduction: a process requiring calcium phosphate and BMP/Wnt signaling. J Cell Mol Med, in press.

Follmar KE, Prichard HL, DeCroos FC, Wang HT, Levin LS, Klitzman B, Olbrich KC, Erdmann D (2007) Combined bone allograft and adipose-derived stem cell autograft in a rabbit model. Ann Plast Surg 58: 561-565.

Fraser JK, Wulur I, Alfonso Z, Hedrick M (2006) Fat tissue: an underappreciated source of stem cells for biotechnology. Trends Biotechnol 24: 150-154. 
Helder MN, Knippenberg M, Klein-Nulend J, Wuisman PI (2007) Stem cells from adipose tissue allow challenging new concepts for regenerative medicine. Tissue Eng 13: 1799-1808.

Holy CE, Shoichet MS, Davies JE (2000) Engineering three-dimensional bone tissue in vitro using biodegradable scaffolds: investigating initial cell-seeding density and culture period. J Biomed Mater Res 51: 376-382.

Meijer GJ, de Bruijn JD, Koole R, van Blitterswijk CA (2007) Cell-based bone tissue engineering. PLoS Med 4: e9.

Müller AM, Davenport M, Verrier S, Droeser R, Alini M, Bocelli-Tyndall C, Schaefer DJ, Martin I, Scherberich A (2009). Platelet lysate as a serum substitute for $2 \mathrm{D}$ static and $3 \mathrm{D}$ perfusion culture of stromal vascular fraction cells from human adipose tissue. Tissue Eng Part A 15: 869875.

Muschler GF, Nitto H, Boehm CA, Easley KA (2001) Age- and gender-related changes in the cellularity of human bone marrow and the prevalence of osteoblastic progenitors. J Orthop Res 19: 117-125.

Niedhart C, Pingsmann A, Jürgens C, Marr A, Blatt R, Niethard FU (2003) Complications after harvesting of autologous bone from the ventral and dorsal iliac crest - a prospective, controlled study. Z Orthop Ihre Grenzgeb 141: 481-486.

Ohgushi H, Okumura M (1990) Osteogenic capacity of rat and human marrow cells in porous ceramics. Experiments in athymic (nude) mice. Acta Orthop Scand 61: 431-434.

Ohgushi H, Goldberg VM, Caplan AI (1989) Heterotopic osteogenesis in porous ceramics induced by marrow cells. J Orthop Res 7: 568-578.

Park MS, Kim SS, Cho SW, Choi CY, Kim BS (2006) Enhancement of the osteogenic efficacy of osteoblast transplantation by the sustained delivery of basic fibroblast growth factor. J Biomed Mater Res B Appl Biomater 79: 353-359.

Planat-Benard V, Silvestre JS, Cousin B, André M, Nibbelink M, Tamarat R, Clergue M, Manneville C, Saillan-Barreau C, Duriez M, Tedgui A, Levy B, Pénicaud L, Casteilla L (2004) Plasticity of human adipose lineage cells toward endothelial cells: physiological and therapeutic perspectives. Circulation 109: 656-663.

Ripamonti U, Richter PW, Nilen RW, Renton L (2008) The induction of bone formation by smart biphasic hydroxyapatite tricalcium phosphate biomimetic matrices in the non-human primate Papio ursinus. J Cell Mol Med 12: 2609-2621.

Sasso RC, LeHuec JC, Shaffrey C, Spine Interbody Research Group (2005) Iliac crest bone graft donor site pain after anterior lumbar interbody fusion: a prospective patient satisfaction outcome assessment. J Spinal Disord Tech 18: S77-S81.

Scherberich A, Galli R, Jaquiery C, Farhadi J, Martin I. (2007) 3D perfusion culture of human adipose tissuederived endothelial and osteoblastic progenitors generates osteogenic constructs with intrinsic vascularization capacity. Stem Cells 25: 1823-1829.

Silber JS, Anderson DG, Daffner SD, Brislin BT, Leland JM, Hilibrand AS, Vaccaro AR, Albert TJ (2003)
Donor site morbidity after anterior iliac crest bone harvest for single-level anterior cervical discectomy and fusion. Spine 28: 134-139.

Thangarajah H, Vial IN, Chang E, El-Ftesi S, Januszyk M, Chang EI, Paterno J, Neofytou E, Longaker MT, Gurtner GC (2009) IFATS series: Adipose stromal cells adopt a proangiogenic phenotype under the influence of hypoxia. Stem Cells 27: 266-274.

Younger EM, Chapman MW (1989) Morbidity at bone graft donor sites. J Orthop Trauma 3: 192-195.

\section{Discussion with Reviewers}

Reviewer I: Should the experiments be reprogrammed using sorted cell populations instead of a total lipoaspirate? It could still be done "intraoperative".

Authors: The concept of sorted cell populations is indeed attractive, and - considering the inter-donor variability in the fractions of cells with different phenotypes - this approach would be crucial to standardize the 'dose' of appropriate cells that need to be delivered per volume of tissue to be regenerated. However, obviously that requires the availability of markers identifying the effectively osteogenic/vasculogenic subpopulations and the demonstration that the other 'accessory' cells do not play a crucial regulatory role.

Reviewer I: How about using marrow stroma as a control? Authors: The use of bone marrow stromal cells is currently being investigated by other groups in a 'one-step' intraoperative perspective. We do not see this independent approach as a possible 'control' of our experimental groups, but sure worth being further pursued. While bone marrow derived cells have a preferential 'commitment' towards the osteogenic lineage, the challenge in using freshly harvested bone marrow is the extremely low number of initially available osteoprogenitor cells, which also limits the possibilities to operate some form of in-line quality control of the available material. Specifically, the number of colony forming unit-fibroblasts, CFU-f, per ml of human fresh bone marrow biopsies is about 100 -fold lower than in adipose tissue (Scherberich et al., 2007, text reference), further decreasing with donor age (Muschler et al., 2001, text reference). Ultimately, the question asked leads thus to the critical issue that an appropriate cell source should provide a suitable balance between the commitment and the number of progenitor cells available. On top of these considerations, it should also be underlined that, in an effort to generate osteogenic and vasculogenic grafts, according to the current state of the art the bone marrowderived cells would not bear any vasculogenic capacity.

Reviewer II: What motivated your decision to use fibrin for wrapping the SVF cells around the scaffolds as opposed to seeding cells directly onto the scaffold surface (e.g., pre-coated with an adhesion molecule such as fibronectin)? MTT staining indicated a heterogeneous application of the cells as aggregates along the scaffold periphery. Do you think this could have reduced cell retention at the ectopic site, and if so, how might the application technique be 
altered in order to improve homogeneity in cell distribution?

Authors:The use of fibrin for wrapping SVF cells around the scaffolds was based on the method proposed by Bensaid and collegues, and was introduced to achieve an instant seeding of cells. Indeed, both a perfusion-based seeding method developed and used in our group (Wendt et al., 2003; Scherberich et al., 2007) and a more typical static loading of a cell suspension require at least a couple of hours before cells are stably adhered to the scaffolds. We are aware of the possible limitations of our method for maintenance of the cells into the construct at the ectopic site. For this reason, in more recent experiments performed for a related project (not yet published), we mixed the polymerizing fibrin gel with granulate materials, as opposed to wrapping it around monolithic, cylindrical foams. The homogeneity of the seeding was improved, but this still did not result in generation of bone tissue by the seeded cells.

Reviewer II: In the discussion, you state that future studies will evaluate modifications to the intraoperative protocol that incorporate growth factors, instructive biomaterials, or perhaps both to enhance bone repair by SVF cells. Given that these cells are clonogenic yet non-expanded, might a two-pronged stimulation - first to initiate a period of cell expansion, then to direct osteogenic differentiation - be advantageous over introduction of a single stimulus?

Authors: It would indeed be highly relevant to induce a sequential stimulation which would first promote cell proliferation, to reach the important target of a higher cell density, and to later drive cell osteogenic commitment. Strategies to release different factors at different kinetics, for instance based on incorporation into polymeric materials and microspheres, have already been achieved by different groups. However, the practical implementation into a clinical setting of such strategies may not be straightforward in terms of regulatory issues and costs, and could thus represent a main limit of what is envisioned to be a practical, simple solution to generate osteogenic grafts in the setting of the operating room at low additional cost.

\section{Supplementary Reference}

Wendt D, Marsano A, Jakob M, Heberer M, Martin I (2003) Oscillating perfusion of cell suspensions through three-dimensional scaffolds enhances cell seeding efficiency and uniformity. Biotech Bioeng 84: 205-214. 